ON THE SPECIES AND RACES OF THE YELLOW WAGTAILS

FROM WESTERN EUROPE TO WESTERN NORTH AMERICA

\author{
BY \\ C. H. B. GRANT $\frac{\text { and }}{\text { anf }}$ \\ C. W. MACKWORTH-PRAED \\ Xnf
}

Pp. 253-268; Pls. 33-35

\begin{abstract}
BULLETIN OF
THE BRITISH MUSEUM (NATURAL HISTORY)

ZOOLOGY

Vol. I No. 9

LONDON : I952
\end{abstract}


THE BULLETIN OF THE BRITISH MUSEUM (NATURAL HISTORY), instituted in I949, is issued in five series, corresponding to the Departments of the Museum.

Parts will appear at irregular intervals as they become ready. Volumes will contain about three or four hundred pages, and will not necessarily be completed within one calendar year.

This paper is Vol. I, No. 9 of the Zoology series. 


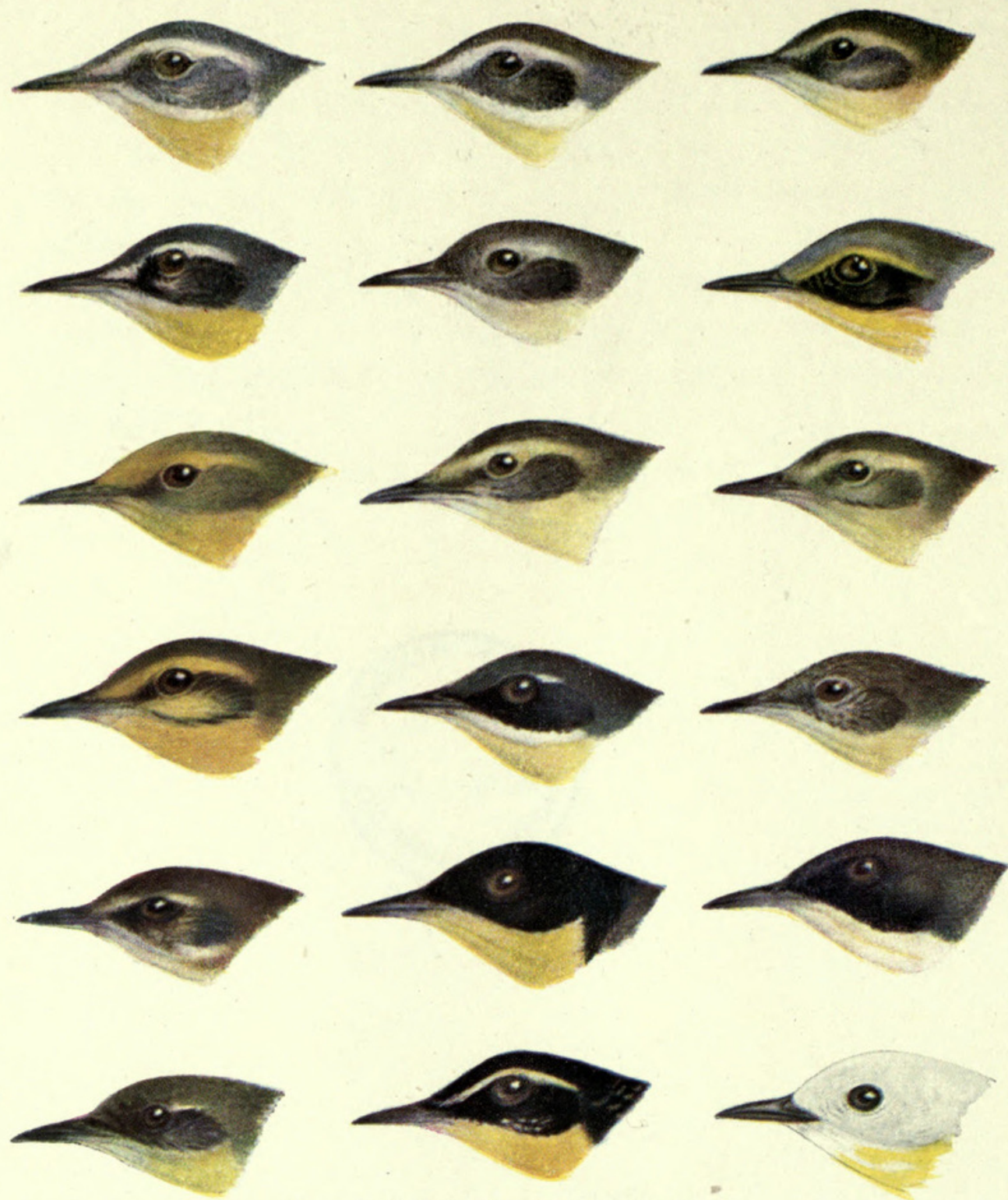

Drawn by H. Grönvold and C. E. Talbot Kelly.

Blue-headed Yellow-Wagtail, male Budytes flavus flavus

Budytes flavus dombrowskii, male

Yellow Wagtail, male Budytes luteus luteus

Budytes luteus flavissima, male

Dark-headed Yellow-Wagtail, young Budytes thunbergi thunbergi

Black-headed Yellow-Wagtail, young Budytes feldegg
Blue-headed Yellow-Wagtail, female Budytes flavus flavus

Budytes flavus dombrowskii, female

Yellow Wagtail, female Budytes luteus luteus

Dark-headed Yellow-Wagtail, male Budytes thunbergi thunbergi

Black-headed Yellow-Wagtail, male Budytes feldegg

White-browed Yellow-Wagtail Budytes superciliaris
Blue-headed Yellow-Wagtail, young Budytes flavus flavus

Yellow-browed Yellow-Wagtail, male Budytes perconfusus

Yellow Wagtail, young

Budytes luteus luteus

Dark-headed Yellow-Wagtail, female Budytes thunbergi thunbergi

Black-headed Yellow-Wagtail, female Budytes feldegg

White-headed Yellow-Wagtail, male Budytes leucocephalus 


\title{
ON THE SPECIES AND RACES OF THE YELLOW WAGTAILS FROM WESTERN EUROPE TO WESTERN NORTH AMERICA
}

\author{
By c. H. B. GRANT and C. W. MACKWORTH-PRAED \\ (Received I5.v.5I)
}

\section{SYNOPSIS}

An endeavour has been made to collect all the known relevant facts on this group and to show that it is not correct to place all the Yellow Wagtails in one species. The authors have based their main conclusions on adult males, and the measurements given are only of adult males from the breeding area, so that a true comparison can be given, and there can be no confusion with measurements of specimens from the non-breeding areas which may have been misidentified by us. It is perhaps of interest to note that the southern species have usually a white chin and throat and the Far Eastern tend to have a longer hind claw.

The normal migration route appears to be mainly north and south, although there is largely a tendency to a north-eastern to south-western movement.

Measurements appear to be of little value in determining the species and races except perhaps in the case of the hind claw of $B$. thunbergi macronyx.

There is still much to learn about this group, especially the exact breeding-ranges of the species and races.

It should be remarked that adult males of all species and races are inclined to have some olivaceous green on the crown, or yellow in B. leucocephalus, and a broken spotted collar in both sexes. These are not specific or racial characters and may be individual retention of juvenile plumages.

A total of 2,594 specimens have been examined.

MANY authors ${ }^{I}$ have written on this group, adding considerably to our general knowledge, and several have described new races. We have lately had occasion to study these Wagtails critically, with especial regard to those species and races which occur in Africa during the non-breeding season. We found it necessary, however, to survey the whole group.

The usual English practice has been to place all as races of one species, Budytes flavus (Linnaeus), but several authors have divided them into a number of species. We have examined all the literature we can find, the large series of specimens in the British Museum collection, and had the kind loan of specimens from Colonel Meinertzhagen, Colonel Payn, Major Payn, M. Mayaud, Dr. K. H. Voous, the Copenhagen Museum, the South African Museum, the Royal Natural History Museum, Stockholm, and the Coryndon Museum, Nairobi.

We are of the opinion that the genus Budytes should be retained as these Yellow Wagtails have somewhat different habits to the Black and White Wagtails, and behave more like Pipits in many respects. It is very unfortunate that we are so out of touch with the Russian museums, as no doubt they have series of birds from the breeding areas which would have been most valuable to examine, but no doubt a number of them have been recorded in the Russian journals we have consulted.

The maps we give not only show the known breeding-areas and limits of movements in the non-breeding season, but also the comparatively vast areas in Europe and

I The bibliography at the end of this article covers the principal references on this group. 
Asia from which no breeding birds have been recorded, and surely some of theseespecially along the rivers-must hold ground suitable to the Yellow Wagtail, although Sushkin (I925) states that apparently none are found breeding in the lower part of the Kobdo basin.

Our long and very careful examination convinces us that those authors who recognize several species are correct, and the maps we give show that there is in several cases an overlap in breeding distribution, a fact supporting the recognition of species. We have divided this group into seven species and would remark that Budytes flavus becomes paler on the head as it goes eastward, the palest being a specimen from Lake Aral, and where the breeding area of this race and $B$. f. beema meet specimens show characters of both. We feel sure that Budytes thunbergi, $B$. luteus, and $B$. feldegg should be treated as species and that $B$. superciliaris and $B$. leucocephalus are also recognizable as distinct species. In the course of this examination we have decided to name a new race and a new species, one from Lake Alakul on the Mongolian border, west of Dzungaria, on a single male that does not fit in with any other Yellow Wagtail without an eyestripe, and the other from five adult male specimens that are all so exactly alike and with such distinct characteristics that it would be unbelievable they do not represent an undescribed species. On the original labels of two from Khartoum A. L. Butler recorded his opinion that they are 'possibly hybrids $M . f$. rayi and $M$. flava', and on the male from the Copenhagen Museum 'rayi $\times$ flava?', but we do not think that this is so, as their characteristics do not fit in with what would be expected of such an intermediate and they are all exactly alike.

The Yellow Wagtails have been credited with being a very variable group and any specimen not fitting into the general rule was merely passed over as an aberrant. This we consider a mistaken and dangerous point of view liable to obscure completely the true picture. Individual variation there is, but within the species. We do not find this group particularly difficult to disentangle and we advance no theories about it (Johansen, I946), having based our conclusions on the facts as shown by specimens and the recorded known breeding distribution. Young birds in their first plumage in all the species are more or less ashy above with dusky centres to the feathers; a blackish streak between the crown and light eyestripe; below more or less buffish white with a black moustachial stripe joining up to an almost perfect collar on lower neck. In $B$. feldegg the dusky centres to the feathers of the upper parts are broader and darker, and in the $B$. luteus group these markings are almost absent and there is a tendency to a yellow wash on the lower belly. In this dress they can be named from the local population in which they occur, as they do not apparently leave their breeding grounds until they have moulted into an immature (intermediate) dress. In this immature dress they are found in their non-breeding quarters, and as the species and races may occur in mixed flocks it is not easy to name them correctly.

Comparison with correctly identified adult females does reveal certain similarities by which the majority can be named, but no written description can give those small differences which the eye can spot when the group as a whole is closely and meticulously studied. Even so, every immature specimen can by no means be named with absolute certainty. 
It has been said that there is a difference in length of tail between B. flavus flavus and $B$. flavus beema and other named races, but we have measured birds from the breeding areas and cannot agree that this is so.

The seven species which we recognize can be distinguished as follows:

A. A streak from base of bill to over and behind eye in male:

\section{Budytes flavus (Linnaeus). Blue-headed Yellow Wagtail}

\section{Budytes flavus flavus (Linnaeus)}

Motacilla flava Linnaeus, I758, Syst. Nat. roth ed.: 185, South Sweden. (For synonyms see Hartert, 1905, Vög. Pal. Fauna: 287.)

Adult male. A distinct white streak from base of bill to over and behind eye, very rarely indeed broken over the eye; head and neck and sides of face grey (variable individually); usually flecked with white on ear-coverts; usually some white on chin; rest of underparts bright yellow; sometimes some spots on lower neck. Wing 77-85, hind claw $6-\mathrm{II}$, tail $67-74 \mathrm{~mm}$. Twenty-one males from breeding area measured, a total of 474 specimens examined.

The female has the head and neck more olivaceous; below, chin and neck buffish white; rest of underparts pale yellow; often with spots on lower neck.

Distribution: Breeding southern Norway, southern Sweden, southern Finland, eastern England (rarely) to northern, western, and central France, middle Europe and the Caspian Sea; in non-breeding season to Africa throughout and Arabia.

Mayaud, I949, states that at Oléron, western France, intermediates occur between $B$. flavus and B. fasciatus. Through the kindness of Dr. Mayaud we have seen three breeding males, Mayaud Nos. 2333, 2334, and 2335, all taken in May, and consider them to be B. f. flavus.

In British Birds: 86, I949, Stuart Smith and Ramsden record a variant yellow Wagtail breeding in the hills near Higher Disley in Cheshire in June. They do not quite agree as to the exact markings of the head of the male and, anyway, such sight records are most difficult to fix and are often not worthy of being recorded. It would appear that this is possibly another record of Budytes f. flavus breeding in England.

\section{Budytes flavus beema Sykes}

Budytes beema Sykes, 1832, Proc. zool. Soc. Lond.: 90, Deccan, India, of which Budytes dubius vel anthoides Hodgson, I844, in Gray's Zool. Misc.: 83 (nom. nuda) and Budytes brevicaudatus Homeyer, 1878, J. Orn. Lpz., I31, Etawah, north-western India, are synonyms.

Adult male: Head and neck pale french grey, variably darker or paler. In freshly moulted dress the mantle is lighter and yellower than in the breeding season. Wing 76-8I, hind claw 9-10, tail 67-72 $\mathrm{mm}$. Nine males from breeding area measured; a total of 320 specimens examined. Where this race meets the nominate race specimens may be placed in either. The female is not distinguishable from the nominate race.

Distribution: Breeding from the Ural Mts. and Caspian Sea to Tomsk and Turkestan; in non-breeding season to the Sudan, Kenya Colony, Nyasaland, Arabia, and 
India. Main non-breeding quarters appears to be India. One specimen from Valencia, Spain in April.

\section{Budytes flavus fasciatus Zander}

Budytes fasciatus Zander, I85I, Naumannia 1 (4): 19, southern France, of which Motacilla flava iberiae Hartert, I921, Vög. Pal. Fauna 3: 2097, southern France, is a synonym, but if these Yellow Wagtails are placed in the genus Motacilla the latter name must be used as Motacilla fasciata (Zander) is preoccupied by Motacilla fasciata Bechstein.

Adult male: White streak from base of bill to over and behind eye; chin to neck in front white. Wing $75-82$, hind claw $8-\mathrm{II}$, tail $67-72 \mathrm{~mm}$. Fifty-seven males from breeding area measured, a total of ninety-six specimens examined. The female also has the chin to neck in front white; the head is duller grey and below, pale or buffish yellow, often with spots forming a sort of collar on the lower neck. In fresh dress the head is more olivaceous.

Distribution: Breeding Spain, Portugal, eastern Pyrenees to western areas of southern France as far east as the Camargue, the Balearic Islands, and Morocco; in non-breeding season to Italy, Morocco, Algeria, Tunisia, and French Sudan.

Wardlaw Ramsay, I923 (Birds of Europe and North-west Africa: 6I) states that this race breeds in Algeria, and this has been quoted by other authors. We cannot find any evidence in support of this. Mayaud (I949), states that along the south coast of France between the Pyrenees and Provence intermediates occur between $B . f$. fasciatus and $B$. cinereocapillus. Through the kindness of Dr. Mayaud we have examined four breeding males from the Etang de Salies and the Camargue, Mayaud's Nos. 729, I059, I066, and I069. All these have a white stripe from base of bill to over and behind eye and are we consider B. f. fasciatus.

\section{Budytes flavus dombrowskii Tschusi}

Budytes flavus dombrowskii Tschusi, 1903, Orn. Jb., 14: 16-1, Pantelimon, Rumania.

Adult male: Differs from B.f. flavus in having the ear-coverts darker; chin usually white; upper throat often white. Wing $8 \mathrm{I}-87$, hind claw $8-\mathrm{Io}$, tail $72-75 \mathrm{~mm}$. Five males from the breeding area measured, a total of fifty-five specimens examined.

Distribution: Breeding Rumania and Serbia in Yugoslavia; in non-breeding season to Palestine, Iraq, and Africa as far south as the Sudan and Abyssinia.

The female apparently differs from that of the nominate race in having rather darker ear-coverts, but we have seen no specimens from the breeding area and without these it is wellnigh impossible to give the comparative female characters.

\section{Budytes flavus plexus Thayer \& Bangs}

Budytes flavus plexus Thayer \& Bangs, I9I4, Proc. New Engl. Zool. Cl. 5: 4I, Nijni Kolynsk, Kolyma, eastern Siberia.

Adult male: A narrow white streak from base of bill to over and behind eye; head, neck, and sides of face dark grey; lores and ear-coverts blackish; chin white; throat yellow. Wing 83-84; hind claw II-I2, tail $72-75 \mathrm{~mm}$. Two males from breeding 
area measured, a total of forty-four specimens examined. Thayer and Bangs give wing $8 \mathrm{I}-82$, tail $68-70 \mathrm{~mm}$. for two males.

The female has a duller grey head often with an olivaceous wash, and usually has the chest more or less washed with chrome yellow and some dark spotting.

Distribution: Breeding northern areas of western and eastern Siberia as far west as the Petchora River; in non-breeding season to Iraq, India, and China.

\section{Budytes flavus zaissanensis Poljakow}

Budytes flava zaissanensis Poljakow, I9II, Messager orn. Mosk., 313: Lake Zaissan, west of Mongolian border, Turkestan.

Adult male: A narrow white streak from base of bill to over and behind eye; head slate grey; mantle olive-green; agreeing very closely with some specimens of $B$. thunbergi in these last two characters. Wing 77-84, hind claw 9-1o, tail $67-78 \mathrm{~mm}$. Two males from the breeding area measured, a total of nine specimens examined.

We have not examined the female nor can we find any description of it.

Distribution: Breeding Barnaul to junction of Altai and Irtysh Rivers and Lake Saissan; in non-breeding season to Sind, Punjab, and Bengal, India, Thailand, and West Java.

Remarks: Poljakow compares this race to B. f. flavus and B. thunbergi. Sushkin, I925, gives wing $77-80$, hind claw $9 \cdot 3$, tail $66-72 \cdot 7 \mathrm{~mm}$.

\section{Budytes flavus angarensis Sushkin}

Budytes flava angarensis Sushkin, 1925, Proc. Boston, Soc. Nat. Hist. 38: 33, Sharagolo-Kaia, Chikoi River, Transbaikalia.

Adult male: A white streak from base of bill to over and behind eye; mantle and borders of wing coverts less bright than $B . f$. zaissanensis. Wing 78-83, hind claw 9.5-I3, tail 72-74 mm. (Sushkin).

Distribution: Breeding Lake Yevsi, Tunguzka and Angara Rivers to Lake Baikal, and the Chikoi River; in non-breeding season to China and Thailand.

We have not seen any specimens from the breeding area, but an adult male with a narrow white streak from base of bill to over and behind eye, which does not fit in with any other Eastern race, we consider is attributable to this race. It is from Pekin and was taken in May: Brit. Mus. Reg. No. I949-9-243. Wing 80, hind claw 9, tail $7 \mathrm{I} \mathrm{mm}$., and an adult male from Bangkok, Thailand, taken on 20 April I93I, now in Raffles Museum, agrees with this specimen. Sushkin has compared $B . f$. angarensis to $B$. flavus, B. simillimus, and B. zaissanensis. The two immature birds mentioned by Sushkin, I925, taken in the Ordos area are probably of this race, but no date or measurements are given nor is any mention made about an eye stripe. The characters given are insufficient to determine them and both are evidently in immature dress as they are stated to be moulting from the young dress. It would therefore appear that they were bred in that area, and maybe $B$. f. angarensis breeds as far south as Ordos. 
Budytes flavus simillimus Hartert

Budytes flava simillimus Hartert, 1905, Vög. Pal. Fauna, 1: 289, Kamschatka, Siberia.

Adult male: A white streak from base of bill to over and behind eye; head and nape rather darker grey than $B . f$. plexus; lores and ear-coverts as in $B . f$. plexus; mantle darker, more olive, less yellow-green. Wing $80-82$, hind claw $9 \cdot 5-\mathrm{II}$, tail 64-69 mm. Three males from breeding area measured, a total of 3 I9 specimens examined. The female has the head olivaceous ashy slightly contrasting with the mantle; below, white or buffish-white; lower belly washed with pale yellow. Hind claw often longer than the females of other races. The immature dress is ashy above, often slightly olivaceous; rump greyer; below, creamy white; chest buffish; under tail-coverts often washed with pale yellow. In this dress it can be confused with Budytes citreola Pallas, though this species has a faint wash of yellow or buff on the forehead and the notch on the third primary I8-20 mm., up the feathers from the tip, this notch lying between the 7 th and 8 th primary, whereas in this race the notch on the 3 rd primary is $15-16 \mathrm{~mm}$., from the tip and lies between the 5 th and 6 th primary (see Sushkin, I925).

Distribution: Breeding Kamschatka; in non-breeding season to India, as far west as the Punjab, Ceylon, Nicobar and Andaman Islands, China, Malay States, Philippine Islands, Dutch East Indies and New Guinea.

\section{Budytes flavus tschutschensis (Gmelin)}

Motacilla tschutschensis Gmelin, I789, Syst. Nat. 2: 962, Tschutschi coast, Bering Strait, eastern Siberia, of which Budytes flavus alascensis Ridgway, 1903, Proc. Biol. Soc. Wash. 16: 105, Western Alaska, is a synonym.

Adult male: A white streak from base of bill to over and behind eye, broader than in $B . f$. plexus; head and sides of face dark grey; mantle darker than other races; chin and upper throat usually white; dusky spots on lower neck; below, more lemonyellow, not bright canary yellow as in $B$. f. simillimus and $B$. f. plexus. Wing $76-8 \mathrm{r}$, hind claw Io-II, tail 66-7I mm. Four males from breeding area measured, a total of twenty specimens examined. The female is similar to the male, but perhaps slightly duller.

Distribution: Breeding north-eastern Siberia and Alaska; in non-breeding season to the Philippine Islands, West Java, and Dutch New Guinea.

Remarks: The two males from the Philippine Islands and one male from Dutch New Guinea, Brit. Mus. Reg. No. I888.7.I2.534 dated November, Brit. Mus. Reg. No. I897.I2.II.43 dated September, and Brit. Mus. Reg. No. I9I6.5.30.857, dated December, agree with this race in general colour and the paler, more lemon-yellow colour below and not with males of $B$. $f$. simillimus.

\section{Budytes luteus (Gmelin). Yellow Wagtail}

\section{Budytes luteus luteus (Gmelin)}

Parus luteus Gmelin, I774, (S. G.) Reise durch Russland, 3: Ior, pl. 20, fig. I, Astrakan, southern Russia, of which Motacilla campestris Pallas, I776, Reise versch. Prov. Russ. Reichs, 3: 696 
Russia; and Budytes flava var. flavifrons Sewertzow 1873, Vert. Geriz. Rashred. Turkest. Zhivoth, Mém. Soc. Amis Sci. Nat. Moscou, 8 (2): 67. Turkestan (nom. nuda), 1875, Stray Feathers, 3: 424; and Budytes chlorocephalus Brehm, I851, Naumannia, 2: 24, Reuthendorf, are synonyms.

Adult male: Head yellow-green; forehead, and streak from base of bill to over and behind eye, yellow. Wing $75-87$, hind claw 8-II, tail 66-70 mm. Eight males from breeding area measured; a total of I05 specimens examined. The female is difficult to distinguish from that of $B$. f. flavus, but it can be said that those with a more uniform head and mantle are this species and those with a greyish head contrasting with the mantle are $B . f$. flavus.

Distribution: Breeding from the Volga River to the headwaters of the Yenisei River; in non-breeding season to central, eastern, and southern Africa as far south as the Transvaal, Socotra Island, Arabia, India, and Ceylon.

\section{Budytes luteus taivanus Swinhoe}

Budytes taivana Swinhoe, 1863, Proc. zool. Soc. Lond.: 234, Formosa Island.

Adult male: Top of head green, uniform with mantle ; lores to ear-coverts olivaceous black; a broad yellow streak from base of bill to over and behind eye; chin and throat bright yellow. Wing $76-87$, hind claw I0-13, tail $67-75 \mathrm{~mm}$. The female differs from the male in being duller in colour. The immature dress can be distinguished from that of $B$. f. simillimus by the yellow in the eye stripe. Twenty males from breeding area measured, a total of eighty-two specimens examined.

Distribution: Breeding from the Lena River and Ija River west of Lake Baikal to the Amur River, also Sakhalin and Kurile Islands, in non-breeding season to Burma, China, Formosa, the Malay Peninsula, Borneo and Dutch East Indies.

\section{Budytes luteus flavissimus (Blyth)}

Motacilla flavissima Blyth, 1834, Loudon's Mag. '\%: 342, England; of which Budytes rayi Bonaparte, 1838, Geog. \& Comp. List Birds Europe \& S. Amer.: I8, British Islands ; Budytes verna (S.D.W.) Wood, I835, Analyst, 3: 31 ; I836, 203; I836, 4 (г6) : 296. Great Britain, nom. nuda; Budytes verna Wood, I836, Brit. Birds: 2 19, Motacilla flaveola Temminck, I835 Man. d'Orn. 2nd ed. 3: 180, England, are synonyms. For other synonyms see Hartert, 1905, Vög. pal. Fauna, 1: 294 .

Adult male: Differs from B. l. luteus in having the forehead uniform in colour with the crown of the head. Wing $72-87$, hind claw $8-\mathrm{II}$, tail $64-74 \mathrm{~mm}$. The female is similar to that of $B$. l. luteus. Fifty-four males from breeding area measured, a total of 233 specimens examined.

Distribution: Breeding southern Norway, southern to eastern British Isles (rarely west Wales, Cornwall, and Devon), Heligoland in most years (Drost, I948), western Holland, western Belgium, northern France, and Channel Islands; in non-breeding season to Africa as far south as the Belgian Congo and Southern Rhodesia.

Breeds alongside B.f. flavus in southern Norway (see Bernhoft-Osa, I944 and I946), and at Dunkirk, Pointe de Raguenes near Nevez, Finisterre, north-western France (see Mayaud, I949, Ibis: I7I). Dr. Holger Holgersen found it breeding in southern Norway in I947 and I949 and considers it to be a regular summer breeder. 


\section{Budytes superciliaris Brehm. White-browed Yellow Wagtail}

Budytes superciliaris Brenm, 1854, J. Orn. Lpz.: 74, Khartoum, Sudan; of which Budytes leucostriatus Homeyer, 1878, 128, Lake Baikal area; Motacilla xanthophrys Sharpe, 1885, Cat. Birds. B.M. 10: 532, pl. 8, fig. 6, Lenkoran, Azerbaijan, southern Russia; and Motacilla flava raddei Harms, 1909, Orn. Mber. 1\%: 2 ; Aschabad, Transcaspia, are synonyms. Hartert, 1905, Vög. pal. Fauna, 1: 293, considers $M$. $f$. vaddei to be an aberrant B. l. taivanus. Although we have not seen the type of Budytes leucostriatus, Homeyer gives the head as clear grey-black with a broad white stripe from the base of the bill to over and behind the eye. These characters agree with $B$. superciliaris and not with B.l. taivanus of which it is placed as a synonym by Hartert, 1905, Vög. pal. Fauna, 1: 298.

Adult male: Top of head to nape jet black to grey-black; nape often grey; centre of crown to nape often olive-green; a white or yellow streak from base of bill to over and behind eye; lores and ear-coverts black with usually some white flecking on latter and under eye; chin white. Wing 77-85, hind claw 10, tail $66 \mathrm{~mm}$. Two males from breeding area measured; a total of thirty-five specimens examined. The female can be distinguished from that of other species by the grey head and mantle with only a slight wash of olivaceous green; below, creamy white with a variable pale yellow wash from lower neck to under tail-coverts; eye-streak buff or buffish white; some spotting at base of neck. The immature dress is very similar to that of the adult female.

Distribution: Breeding southern Iran to Turkestan, also Bulgaria and eastern Yugoslavia; in non-breeding season to Egypt, the Sudan, Abyssinia, Arabia, and India.

Col. Meinertzhagen (I949, Ibis: 472) records seeing a party of four males near Taif, Arabia, sometime between February and April.

\section{Budytes leucocephalus Przevalski. White-headed Yellow Wagtail}

Budytes leucocephalus Przevalski, I887, Zap. Imp. Akad. Nauk. S.-Peterb. 55: 85, ${ }^{\mathrm{I}}$ Dzungaria, northern Turkestan.

Adult male: Whole head to nape, chin and usually upper part of throat white, or white washed with grey; sometimes a white eye-stripe is distinguishable. Wing $8 \mathrm{I}$, hind claw ro, tail $72 \mathrm{~mm}$. One male from breeding area measured; a total of thirty specimens examined. The female is similar to the male. The immature bird has the head and ear-coverts olivaceous grey; a white streak from base of bill to over and behind eye; mantle washed with grey; below, chin and throat whitish washed with yellow; a broken spotted collar at base of neck; chest to under tail-coverts paler yellow than adult.

Distribution: Breeding eastern Russia, Turkestan, and western Mongolia; in nonbreeding season to Africa as far south as north-eastern Northern Rhodesia and northern Nyasaland, Arabia and north-western India.

Remarks: Sushkin found the character of the head constant in the breeding area at Lake Achit-Nor. The specimens we have examined have a remarkable close resemblance to each other and it should be noted that the sexes are alike, facts which have induced us to place it as a species and not as a very pale headed race of $B$. flavus. We have examined thirty-one adult specimens, four of which are females,

I This Russian version of the Mémoires is apparently not available in Great Britain. 
including one male in the Meinertzhagen Collection from Orox Nor in May, and compared them with the coloured Plate ro of the male and female in Bianki I905, Wiss. Res. Przevalski Cent. Asien, Zool., 2, Vög. pt. 4, and find they agree very well with that plate, but it would appear the female figured is in immature dress. Finsch saw light-headed Yellow Wagtails, probably of this species, between the eastern end of Lake Zaissan and the Altai on 6 June, but none were obtained nor are they recorded as breeding there (see Suchkin, I925). A description of this species was also published in Ibis, I887: 40I, but the one in the Russian journal has priority of date. Through the kindness of Dr. Barnard, Director of the South African Museum, we have had on loan the specimen recorded in J. S. Afr. Orn. Un. 2: 92 (Igo6), from Kanyani, Northern Rhodesia, as 'Motacilla flava beema?' and find that it agrees perfectly with the Brit. Mus. series of this species:

\section{Budytes perconfusus Grant \& Praed. Yellow-browed Yellow Wagtail}

Budytes perconfusus Grant \& Praed, I949, Bull. Brit. orn. Cl. 69: I3o, Khartoum, Sudan.

Adult male: Above mantle rather darker than B. luteus and below rather paler yellow; chin and throat yellow; forehead to forecrown grey; a clear grey collar on hind neck; crown olive-green; a broad pale yellow streak from base of bill to over and behind eye; lores to ear-coverts darker grey with white flecking. Differs from $B$. flava in the yellow streak over the eye and the paler grey head. Wing 78-85; hind claw 9-II; tail 68-70 mm.

In fresh dress the forehead and nape is more washed with olivaceous green; the mantle is darker; the tips of the wing-coverts brighter yellow-green and only a few white flecks on the ear-coverts; streak over eye yellow, not white or buff or washed with buff, as in B. flavus flavus in fresh dress.

The female and young bird also have a yellowish eye streak.

Distribution: Known only from scattered specimens from Frederikhavn, northeastern Denmark, Pomerania, Germany, Wassenaar near The Hague, Holland, Abyssinia, the Sudan, and western Arabia.

As stated above the five adult male specimens are exactly alike; the two from Khartoum, Brit. Mus. Reg. Nos. I9I5.I2.24.I429 and I436 and Pomerania, Brit. Mus. Reg. No. I94I.5.30.8I9, were taken in April, the one from Denmark was taken on 3 May, and the one from Holland was taken in September. In the non-breeding season this species visits Abyssinia, the Sudan, and western Arabia and passes through Holland, Denmark, and Pomerania. A total of ten specimens examined, including a male from Fashoda, Sudan, March, Brit. Mus. Reg. No. I902.4.20.I42; a male from Khartoum, Sudan, December, Brit. Mus. Reg. No. I9I5.I2.24.I445; two males from Abyssinia, February and November, Brit. Mus. Reg. No. I927.II.5. 653, and 1934.8.9.352; and a female from Arabia, September, Brit. Mus. Reg. No. I935.5.I0.78. We had considered placing it as a race of $B$. flava, but we feel that it is better treated as a species. We are confident that one day the breeding area will be discovered.

$B$. No streak from base of bill to over and behind eye in male, though sometimes a short white mark behind eye:

Zoo. I. 9. 
Budytes thunbergi (Billberg). Grey-headed Yellow Wagtail

\section{Budytes thunbergi thunbergi (Billberg)}

Motacilla thunbergi Billberg, I828, Syn. Faun. Scand. 1 (2) Aves: 50, Lapland. For synonyms see Hartert, 1905, Vög. pal. Fauna 1: 291.

Adult male: Head dark grey to near coal black; no streak over eye, occasionally a short white mark behind eye; more rarely a similar mark in front of the eye; chin and throat yellow; some spotting on lower neck in front. Wing 80-85, hind claw 8-II, tail $69-74 \mathrm{~mm}$. Twenty-seven males from the breeding area measured; a total of 243 specimens examined. The female and immature are practically indistinguishable from that of $B$. flavus flavus, though perhaps some have rather a darker coloured top to the head.

Distribution: Breeding northern Norway and northern Sweden to Finland and northern Russia as far east as the lower Yenisei River, also Estonia; in non-breeding season to Africa as far south as Damaraland and the Transvaal, Arabia, India, Burma, and the Malay Peninsula.

Remarks: S. Armington I949, records at Ladugardsgarde, north-east of Stockholm, having observed a male Yellow Wagtail in the summer of 1947 which agreed perfectly with $B$. thunbergi. This bird was with a female which was indistinguishable from the female of $B$. f. flavus, but the nest was not located. About twenty pairs of B. f. flavus were breeding in the same locality. At the same place in 1949 Armington observed a male and female, the male agreeing with $B$. thunbergi, but had a superciliary streak over the right eye and a small patch behind the left eye. It is difficult to comment on the above, as there are no specimens to examine, but would remark that as $B$. thunbergi breeds in Finland and Estonia, it could be found breeding on the same latitude near Stockholm.

As many females of both $B$. thunbergi and B. flavus are practically indistinguishable in skins and quite indistinguishable in the field, it cannot be said that the female with the Ladugardesgarde male was other than a $B$. thunbergi. As regards the male seen in I949 as having a stripe over the right eye, this may have been a retention of the immature dress, but there is no proof that this is so.

Jordans, I923, mentions fifteen males of $B$. f. flavus taken near Upsala, Sweden, in May with varying coloured heads from pale grey to a darker or lighter crown, all having a superciliary stripe, and a series from Lapland which varies in a similar way, of which the lightest matches the darkest B.f. flavus, and others show all intergradations from this type to an almost black crown. Twenty per cent. have a light superciliary stripe indicated or even quite distinct. Count Gyldenstolpe has kindly picked out five representative specimens from this series and sent them to us for examination, and remarks in a letter to us dated 4 October I949, 'B. $f$. thunbergi is found at Upsala during its migrations in May, together with $B$. f. flavus, hence the statements made by Jordans'.

All these five specimens are clearly $B$. thunbergi thunbergi; the Lapland ones all taken in June and the Upsala ones on 6 and I2 May. One from Lapland, taken on I6 June I93I, which has the dark head and ear-coverts of $B$. $t$. thunbergi has an indication of a white streak before as well as behind eye, but not over the eye. All 
have some spotting on the lower neck in front. It would appear that Jordans considered this Lapland specimen of I6 June I93I as an intermediate between B. flavus and $B$. thunbergi, but we are satisfied that this specimen is $B$. thunbergi, and not an intermediate between that species and B. flavus.

\section{Budytes thunbergi cinereocapillus (Savi)}

Motacilla cinereocapilla Savi, 1831, Nuovo Giorn. Lett. Pisa, 22, I9o, Tuscany, Italy.

Adult male: Differs from the nominate race in having the chin and neck in front white, or rarely some yellow mixed with the white on the lower neck in front. Wing $8 \mathrm{I}-83$, hind claw 9-II, tail $70-72 \mathrm{~mm}$. Nine males from breeding area maesured, a total of thirty-one specimens examined. The female and immature are practically indistinguishable from those of $B . f$. fasciatus, both having a streak from the base of the bill to over and behind eye.

Distribution: Breeding southern France to Italy, Dalmatia, Switzerland, and Algeria ; in non-breeding season to western, northern, and eastern Africa as far south as Senegal and Uganda, also Arabia.

Kirkman \& Jourdain, I9I3, British Bird Book, Vol. 4: 477, state that this race breeds in Tunis, and this has been quoted by other authors. We cannot find any evidence in support of this.

Remarks: Thönen (I948) records and figures the head of a Yellow Wagtail breeding at Lake Neuenburger, near Basle, Switzerland.

This figure and the description agrees well with specimens in the British Museum collection of Budytes thunbergi cinereocapillus which has in some specimens the pure white more confined to the throat and a white fleck behind the eye. This figure was drawn from life, as the bird was not collected. Ticehurst and Whistler (I927) state that this race is found in the plains and $B . f$. fasciatus in the mountains, but Ticehurst obtained a male of $B . f$. fasciatus in June at Argelès-sur-Mer. It would thus appear that both breed in the same area. The single record of this race from Great Britain can be accepted. There is little doubt that it was collected near Marazion Station. The specimen has disappeared, but there is an excellent coloured figure of it in Gould's Birds of Gt. Britain, 3: pl. 5, 1873.

Budytes thunbergi pygmaeus Brehm.

Budytes pygmaeus Brehm, 1854, J. Orn. Lpz:: 74, (note), north-east Africa.

Adult male: Similar to B. t. cinereocapillus but smaller in size; chin and throat sometimes yellow; often an olive-green patch on crown of head and a white streak behind eye. Wing 70-78, hind claw 8-10, tail $58-67 \mathrm{~mm}$. The female is very similar to that of B.t.cinereocapillus, but is smaller; sometimes a white mark behind eye. Thirty-six specimens examined.

Distribution: Egypt.

Budytes thunbergi macronyx Stresemann.

Budytes flavus macronyx Stresemann, I920, Avifauna Macedonica: 76, Vladivostock, eastern Russia.

Adult male: Differs from the nominate race in having a rather darker mantle and 
a longer hind claw; chin white; sometimes a short white mark behind eye. Wing 78-84, hind claw Io- 15 , tail $69-75 \mathrm{~mm}$. Fourteen males from breeding area measured, a total of seventy-one specimens examined. The female has the head olivaceous green or olivaceous grey; sometimes a short light mark behind eye. The immature dress is grey or olivaceous grey above and creamy white below.

Distribution: Breeding Siberia; in non-breeding season in China, Siam, Burma, Indo-China, Philippine Islands, Singapore, Borneo, Sumatra and Java.

\section{Budytes thunbergi alakulensis Grant \& Praed.}

Budytes thunbergi alakulensis Grant \& Praed, 1949, Bull. Brit. orn. Cl., 69: I3I, Lake Alakul, Turkestan.

Adult male: Similar to Budytes thunbergi thunbergi, but head rather darker, more coal black. Wing 80 , hind claw 8 , tail $68 \mathrm{~mm}$.

Distribution: Breeding Lake Alakul; in non-breeding season to Kiukiang, Yangtse River, China.

Two specimens examined.

\section{Budytes feldegg (Michahelles). Black-headed Yellow Wagtail}

Motacilla feldegg Michahelles, I830, Isis: 812, Split, Dalmatia, Yugoslavia; of which Budytes melanogrisea Homeyer, 1878, J. Orn. Lpz.: I28, India; Budytes aralensis Homeyer, 1878, J. Orn. Lpz.: I28, Lake Aral (compared to B. feldegg, head given as coal black; below lemon yellow); Budytes flava suschkini Domaneiwski, 1925, Ann. Mus. Zool. Polon, 4: 95 \& 107, no type locality; and Motacilla kaleniczenkii Kaleniczenko, 1839, Bull. Soc. Nat. Moscou: 229, pl. 20, Crimea, are synonyms.

Adult male: Forehead to nape, sides of face, ear-coverts and sides of neck jet black to coal black; sometimes variable white streak between black face and yellow throat ; chin and throat yellow; often some green on top of head and some grey at nape. Can be distinguished from $B$. superciliaris in having no streak from base of bill to over and behind eye. Wing 78-85, hind claw 9-II, tail $66-76 \mathrm{~mm}$. Thirty-three males from breeding area measured; a total of 377 specimens examined. The female and immature plumages are similar to those of $B$. superciliaris, but there is no streak from the base of the bill to over the eye, though sometimes there is a short light mark behind the eye.

Distribution: Breeding in Montenegro, Serbia in Yugoslavia, Albania, Greece, Turkey, and Syria to the Black and Caspian Seas, Lake Aral, north-western Iran, and Turkestan; in non-breeding season to southern France, eastern Africa as far south as Uganda and Kenya Colony, southern Arabia, Socotra Island and India.

In adult females there is considerable individual variation on the head which does not appear to have any relation to the breeding and non-breeding season. These variations are well shown in $\mathrm{Pl}$. I, Ibis, I932, though the black colouring in figs. 3 , 4 , and 5 is much too dull. Rarely males have the mantle grey with a slight olivaceous wash; below, chin and throat white with a faint touch of yellow; rest of underparts very pale yellow. A plumage very similar to some adult females. The four specimens 


\section{$2 \mathrm{BHL}$ Biodiversity Heritage Library}

Grant, C. H. B. and Mackworth-Praed, C W. 1952. "On the species and races of the Yellow Wagtails from western Europe to western North America." Bulletin of the British Museum (Natural History) Zoology 1, 253-268.

https://doi.org/10.5962/bhl.part.21633.

View This Item Online: https://www.biodiversitylibrary.org/item/19429

DOI: https://doi.org/10.5962/bhl.part.21633

Permalink: https://www.biodiversitylibrary.org/partpdf/21633

\section{Holding Institution}

Natural History Museum Library, London

\section{Sponsored by}

Natural History Museum Library, London

\section{Copyright \& Reuse}

Copyright Status: In copyright. Digitized with the permission of the rights holder.

Rights Holder: The Trustees of the Natural History Museum, London

License: http://creativecommons.org/licenses/by-nc-sa/4.0/

Rights: http://biodiversitylibrary.org/permissions

This document was created from content at the Biodiversity Heritage Library, the world's largest open access digital library for biodiversity literature and archives. Visit BHL at https://www.biodiversitylibrary.org. 